\title{
The Demand for Military Expenditure in Developing Countries:
}

\section{Hostility versus Capability}

\author{
J Paul Dunne \\ University of the West of England \\ John2.dunne@uwe.ac.uk \\ Sam Perlo-Freeman \\ University of the West of England \\ Samuel.perlo-freeman@uwe.ac.uk \\ Ron P Smith \\ Birkbeck College, London \\ R.smith@bbk.ac.uk
}

01 July 2007

\begin{abstract}
This paper has considers the interpretation of the empirical results of the developing literature on the demand for military spending that specifies a general model with arms race and spillover effects and estimates it on cross-section and panel data. It questions whether it is meaningful to talk of an 'arms race' in panel data or cross-section data, and suggests that it may be more appropriate to talk about the relevant variables - aggregate military spending of the 'Security Web' (i.e. all neighbours and other security-influencing powers) and the aggregate military spending of 'Potential Enemies'- as acting as proxies for threat perceptions, which will reflect both hostility and capability.
\end{abstract}

Keywords: Military Spending, Developing Countries, Demand.

JEL Code: H56, C33

Demand ACDA data 1

No. words: 4755

Preliminary draft. Comments welcome, but please do not quote without the authors' permission 


\section{Introduction}

The concept of an 'arms race' is widely used both in colloquial and academic discussion of international relations, generally referring to a competitive pattern of arms acquisitions by two or more countries, usually seen as mutually hostile. The early $20^{\text {th }}$ century naval arms race between the UK and Germany is probably the earliest to receive substantial attention, and the term 'arms race' was used ubiquitously to describe the build-up of nuclear weapons by the US an the Soviet Union during the Cold War. While the question of whether arms races can be said to 'cause' wars is hotly debated, there is evidence that the existence of mutual arms build-ups is associated with an increased likelihood of armed conflict (eg. Bennett \& Stam, 2004), and it is hard to dispute that heavy arms build-ups are likely to increase the intensity and perhaps duration of a conflict, should one occur.

Economists and empirical political scientists, however, have a rather more specific meaning for the term arms race, namely an interactive action-reaction pattern of arms acquisitions and/or military spending increases between two or more countries, where each countries level of military spending/arms depends on that of the other, for some suitable dynamic specification, empirical model and set of conditioning variables. This concept, first proposed by Richardson (1960), has been the subject of extensive analysis for numerous pairs of countries thought to be engaged in arms races, such as the US/USSR, India/Pakistan, Greece/Turkey, Israel/Arab states, etc. - although the empirical success of this research programme has been limited. (Dunne \& Smith, 2007.)

In recent years, a number of authors (including Rosh (1988), Dunne \& Perlo-Freeman (2003a and 2003b) and Collier \& Hoeffler (2004)) have sought to generalise the concept of an arms race by looking at the demand for military expenditure across a large group of countries. Using either cross-section and panel data, incorporating a range of economic, political and security variables, together with variables for the aggregate military expenditure of neighbours and rivals, these models have typically shown that a country's military expenditure is significantly and positively influenced by that of those around them. (in the sense of the 'security web' of Rosh (1988)). Dunne \& Perlo-Freeman (2003a \& b) found that, in particular, it was the military expenditure of 'Potential Enemies' (i.e. those countries with whom the country shared a degree of hostility) that was most important. They suggest that 
this indicates, if not an arms race as such, then at least arms race-like effects, or spill over effects, where there is some tendency towards an action-reaction pattern of military spending between hostile nations. Such studies raised a number of issues that are being dealt with in the recent literature, such as what is actually meant by an 'arms race' or arms-race type effects in panel data, how the large degree of heterogeneity between different countries and dyads (Dunne \& Smith, 2007; Dunne, Perlo-Freeman \& Smith, 2007).

It also raises the issue of whether the nature of the adversarial interactions is being correctly interpreted, in particular whether countries are responding to changes in hostility or capability. This paper considers this issue. The next section discusses the literature on the determinants of military spending, focusing in particular on the question of action-reaction type effects in panel data models. The following section questions more closely the interpretation of these models, suggesting that the concept of an 'arms race' emerging from a panel data study is theoretically and empirically dubious, and that a more fruitful approach may be to look at the interaction of military expenditure and levels of hostility, in the context of the overall relationship between country dyads. Section 4 presents some preliminary empirical investigations, using the same dataset as Dunne \& Perlo-Freeman (2003b), in an attempt to unpack these concepts a little more, and separate the effects of changing military expenditure by a neighbour or rival, and changing levels of hostility. Section 5 then presents some conclusions.

\section{The Determinants of Military Spending}

There are two broad groups of empirical studies in the literature on the determinants of military spending. First, those based on the arms race models of Richardson (1960), which are best suited to situations in which countries are in conflict and have often have failed to perform well empirically (Dunne, 1996; Smith, 1989). Second, there are those studies focusing on a range of economic, political and strategic determinants of military spending, with the most satisfactory empirical analyses tending to take a relatively comprehensive approach. More formal models have been developed from the neoclassical approach, which considers the country or state as maximising a social welfare function with security an integral component (Smith, 1980 and 1995). Most theoretical models lead to similar estimation equations for the empirical analysis, where the demand for military expenditure is 
a function of economic resources, threats to security, and political factors, such as the nature of the state.

$$
\mathrm{M}=\mathrm{D}\left(\mathrm{Y}, \mathrm{P}_{\mathrm{m}}, \mathrm{P}_{\mathrm{c}}, \mathrm{Z}, \mathrm{T}\right)
$$

where $\mathrm{Y}$ is income, $\mathrm{P}_{\mathrm{m}}$ and $\mathrm{P}_{\mathrm{c}}$ are the prices of $\mathrm{M}$ and $\mathrm{C}$ relative to an income deflator, $\mathrm{Z}$ demographic variables and T strategic variables. This equation can then be rewritten as shares in Y rather than levels to give us the demand function commonly used in empirical work Smith, 1989, 1995). More recently these two strands of research have been brought together with arms race dynamics introduced into demand models, giving a more complex structural model than an action-reaction framework and also considering economic, political and military factors. This has also ranged across disciplines, with international relations, political science, sociology, and economics all contributing studies.

An early attempt to deal with strategic effects was the concept of a "Security Web" concept developed by Rosh (1988). This defines neighbours and other countries (such as regional powers) that can affect a nation's security as being part of a country’s Security Web. Rosh calculates the degree of militarisation of a nation's Security Web by averaging the military burdens of those countries in the web, finding it to have a significant positive effect on a country’s military burden. More generally spillover effects have been attracting increasing attention, e.g Murdoch and Sandler (2002, 2004).

Dunne and Perlo-Freeman (2003a) estimated cross-section demand functions for developing countries using average data for Cold War (1981-88) and post Cold War (1990-97) periods. The dependent variable was the log of the share of military expenditure, significant explanatory variables were log population (negative); log of the sum of its 'Potential Enemies 'military expenditure (positive) ${ }^{1}$; log of the sum of the military expenditures of countries in its Security Web (including potential enemies) (positive); a democracy measure (negative); civil war; external war (both positive) and region dummies. There was little evidence of a change in the underlying cross-section relationship with the end of the Cold War. Dunne and PerloFreeman (2003b) estimate a very similar model explaining the log of the share of military expenditure with the same explanatory variables, but rather than averaging the data they use it

\footnotetext{
${ }^{1}$ This includes actual enemies
} 
as an unbalanced panel of annual data for 98 developing countries 1981-1997. The static fixed effects estimates are quite similar to those found in cross-section. One difference is that while the Potential Enemies' military spending variable is still positive and highly significant, the variable for the aggregate military spending in the whole Security Web (including the Potential Enemies subcategory) is actually slightly negative, although insignificant. However, when dynamics are allowed for, through a lagged dependent variable the results are very different. The estimates are obtained by differencing the data to remove the fixed effect, then instrumenting the lagged change in the dependent variable, which becomes correlated with the error term from the differencing. In contrast to the cross-section results there is evidence of structural change, between Cold War and post Cold War periods in the dynamic panel model.

Collier and Hoeffler (2004) use a slightly different approach, taking a pooled static panel of five-year averages and explaining the share of military expenditure by measures of international war, civil war, external threat, international war, democratic government, neighbour's military expenditure, a post-Cold War shift after 1995, log population, log GDP per capita, aid to GDP and a dummy for Israel. They find the effect of neighbour's military expenditure quite large, meaning that increases in military expenditure are escalated among neighbors, making them a regional public bad. They also investigate the endogeneity of a number of variables and find that once instrumented, military expenditure does not deter rebellions. They find that the level of spending of neighbouring governments is an important determinant of a country's military spending (in addition to aid). They also found that the influence of neighbours was emulation rather than threat suggesting that the deterrence of international war was not an important rationale for military spending, suggesting that military expenditure is a regional public bad.

\section{Interpretation}

When considering the estimation of such models using panel data methods, such as fixed effects, or GMM, parameter heterogeneity raises important issues. Where the number of timeperiods is large enough to estimate a separate time-series model for each country, the pattern tends to be that while average effects are sensible there is a very large amount of heterogeneity in the country specific estimates, which may not always appear sensible. It may 
also lead to bias in the estimates, in particular if dynamics are incorporated into a fixed effects model; however the fixed effects estimator can produce consistent estimates of the long-run average parameters if the variables involved are I(1) (Dunne \& Smith, 2007). Parameter heterogeneity also raises a important issue regarding the interpretation of the results of studies such as Dunne \& Perlo-Freeman (2003a \& b) and Collier \& Hoeffler (2004), in particular it raises the question of what we would mean by an 'arms race' in a cross-section or a panel.

An arms race implies an action-reaction pattern of military expenditure. But such a relationship must be particular to a pair of countries, or a group of countries, over a particular time-period. It is not difficult, at the theoretical level, to conceive of an arms-race system, where each country in the system has a different reaction coefficient to each other country in the system, but this is not what we do in a panel data model, where we are estimating an average reaction to an aggregate of military expenditures. To call this an 'average arms race' would be stretching the definition beyond breaking point. It would perhaps be more accurate to say that what we are actually doing is using aggregate military spending of neighbours and rivals as proxies for threat. The results of the aforementioned studies suggest that they are indeed valid proxies, along with others such as the existence of armed conflict.

But threat perceptions amongst neighbouring countries, leading in turn to military expenditure decisions, may be correlated for other reasons than arms races between the countries concerned. They could be the result of common regional threat perceptions, for example instability generated by nearby conflicts, the threat of terrorism, and so forth. It could be more a question of 'a rising tide lifting all boats' than the result of arms races. Alternatively, common political tendencies in a region may affect military spending similarly, e.g. tide of democratisation in South America in 1980s.

Dunne \& Perlo-Freeman (2003a and 2003b) find that it is in fact the military expenditure of rivals (Potential Enemies in their classification) that is of particular importance in determining milex, and indeed in the panel data models of the second paper, they find that the influence of the general Security Web is insignificant or even negative. It is certainly more plausible to talk about arms races between countries who are actually rivals than those who are friendly or neutral, although it is possible that 'emulation' or 'keeping up with the Jones' effects may occur from time to time. But when we consider the use of aggregate military spending of rivals as a variable, we run into another issue: this variable can change either because of 
changes in the military expenditure of a given rival, or because of a change in a country's status as a rival. Threat can be argued to be the product of capability and intention ${ }^{2}$. Thus the Potential Enemies variable represents a very rough measure of such a combined threat concept. The empirical results do not tell us whether it is primarily the change in intentions, or levels of hostility, that is at work, or the change in military spending levels, or a combination of the two. Thus, it does not tell us about arms races in the conventional sense ${ }^{3}$.

In fact, the idea of levels of hostility between two countries being a more important determinant of their military expenditure than an action-reaction effect has been suggested before in the context of India and Pakistan, by Oren (1994). After commenting that previous studies have found every possible combination of signs and significance levels of reaction coefficients between the two, he estimates a model of military spending for India and Pakistan using both military spending levels and an index of hostility, based on events data. He finds that the level of hostility is significant and positive, but that the military spending reaction coefficients are actually negative. And this in the case of what is often seen as the poster-child for Richardsonian arms races.

Insofar as military expenditure decisions are based on threat perceptions, as opposed to internal economic and political factors, it seems over-simplistic to expect to be able to boil these threat perceptions down to the changing military expenditure levels of neighbouring and rival countries. Rather, one would need in principle to consider the changing nature of the relationship between two countries as a whole, and indeed changes to the regional and global security environment. An increase in military expenditure by one country may be seen as a threat under some circumstances, but not in others, depending on the state of relations between the two, the purpose of the military expenditure (e.g. wages, manpower, equipment, etc.) and whether the use to which it is put is perceived as being directed against oneself. Even between two countries locked in an enduring rivalry, such as India and Pakistan or Greece and Turkey, all of these factors will vary considerably over time.

This is not to say that arms races, in the broader sense of competitive patterns of arms acquisitions, do not exist, or are not serious security issues. We may certainly expect, for

\footnotetext{
${ }^{2}$ Or more generally, Threat $=\mathrm{f}($ Capability, Intention $)$, with $\mathrm{dT} / \mathrm{dC}>0, \mathrm{dT} / \mathrm{dI}>0$, and $\mathrm{d}^{2} \mathrm{~T} / \mathrm{dIdC}>0$
} 
example, that two countries in a high state of tension with each other, possibly involving a serious threat of war, are likely to engage in an arms race thus defined. It is the notion of a regular, empirically derivable action-reaction pattern that is questioned here.

\section{Empirical Analysis}

To investigate theses issues further the model in Dunne \& Perlo-Freeman (2003b) is updated, using the same data source, namely ACDA military expenditure data for 98 developing countries for the period 1981-1997. The original model regressed log military burden on log GNP, log population, External War dummy, civil war variable (scale of 0-4), democracy variable (from Polity 4 dataset), log Security Web military spending (aggregate military spending of all countries in security web), Great Power Enemy dummy, and log trade (sum of imports and exports). The results for this are shown in Table 1.

As has been noted, the Fixed Effects estimator does not allow for parameter heterogeneity in the slope coefficients, only in the intercepts. A random coefficients estimator would deal with this problem, but we do not have a sufficient number of time periods for this to be feasible, and too many of the variables are time-invariant for too many countries. But if we are to view the Potential Enemies Military spending variables to be capturing arms race effects, then it would be particularly desirable to get an idea of the different nature of the reactions by different countries to change in their rivals' milex.

One means of allowing for heterogeneous military spending reaction coefficients is to allow each country to have a different coefficient for the Potential Enemies’ military spending variable. ${ }^{4}$ To allow for this country-specific variables were constructed, equal to the Potential Enemies variable times the dummy for each country in question, for those countries who at some stage had non-zero values of this variable. ${ }^{5}$ Thus, each country is allowed to have a different response to the aggregate military spending of its rivals, although homogeneity is still assumed for the other variables. A like response is also assumed for each country to its

\footnotetext{
${ }^{3}$ In the cross-section models of Dunne \& Perlo-Freeman (2003a), this variable tells us that countries with rivals spend more than countries without, and that the more powerful the rivals, the higher the milex, other things equal. Such a result may be quite plausible, but again not even indirectly evidence of arms races.

${ }^{4}$ A similar exercise was done for an updated dataset using SIPRI military spending figures from 1988-2003. Like the current study, this found considerable heterogeneity in both the sign and significance of the variable for rivals' milex, although this study actually found that general Security Web military spending was more significant than specifically that of rivals'. (Dunne, Perlo-Freeman \& Smith, 2007)

${ }^{5}$ The log variables were constructed as $\log ($ aggregate military spending +1$)$, so that 0 values are indeed transformed to 0 .
} 
various different rivals, where it has more than one. Table 1 below shows the regression results for the variables other than the country-specific potential enemies variables.

The results for the other variables were broadly similar to those in Dunne \& Perlo-Freeman (2003b). There are significant negative size effects arising from both population and GNP (although in the original study the population effect was much stronger.) External and Civil war are both significant and positive, as is the Great Power Enemy dummy (much more so than in the original model), while democracy has a significant negative effect. The Security Web military spending variable is negative but insignificant, and log trade is positive.

Table 1: Results for Fixed Effects Model.

\begin{tabular}{|l|l|l|}
\hline $\begin{array}{l}\text { Dependent variable is } \\
\text { log military burden }\end{array}$ & $\begin{array}{l}\text { Model 1: Homogenous } \\
\text { Potential Enemies }\end{array}$ & $\begin{array}{l}\text { Model 2: Heterogenous } \\
\text { Potential Enemies }\end{array}$ \\
\hline Variable & Coefficient (t-ratio) & Coefficient (t-ratio) \\
\hline External War & $0.57^{* * *}(8.4)$ & $0.47^{* * *}(6.7)$ \\
\hline Civil War & $0.11^{* * *}(9.9)$ & $0.12^{* * *}(10.3)$ \\
\hline Great Power Enemy & $0.16^{*}(1.9)$ & $0.53^{* * *}(4.9)$ \\
\hline Democracy & $-0.014^{* * *}(-5.5)$ & $-0.016^{* * *}(-6.2)$ \\
\hline log Population & $-0.26^{* * *}(-3.8)$ & $-0.16^{* *}(-2.0)$ \\
\hline log Trade & $0.087^{* * *}(2.8)$ & $0.065^{* *}(2.1)$ \\
\hline log GNP & $-0.14^{* * *}(-2.9)$ & $-0.14^{* * *}(-3.0)$ \\
\hline $\begin{array}{l}\log \text { Security Web } \\
\text { milex }\end{array}$ & $-0.030^{*}(-1.7)$ & $-0.027(-1.5)$ \\
\hline $\begin{array}{l}\text { Log Potential Enemies } \\
\text { milex }\end{array}$ & $0.039^{* * *}(7.5)$ & Variable \\
\hline $\mathrm{R}^{2}$ (within) (R ${ }^{2}$-bar) & $.23(0.22)$ & -277 \\
\hline Standard Error & .34 & $0.38(0.35)$ \\
\hline Log Likelihood & -438 & .31 \\
\hline
\end{tabular}

Notes: t ratios in brackets 
Of the 48 country-specific potential enemies variables that were not dropped due to multicollinearity, 19 were positive and significant (at least at $10 \%$ level, most at $1 \%$ level), 5 were negative and significant, 16 were positive and insignificant, 8 were negative and insignificant. Coefficient values ranged from -2.5 to +1.9 , and the average coefficient was 0.1 (quite a lot higher than the coefficient value for Potential Enemies in the regression with homogenous coefficients, which was only around 0.03 ). Thus, on the one hand we see that there is a very high degree of heterogeneity amongst the countries in the sample; on the other hand, the fact that around $40 \%$ of the coefficients were positive and significant shows that for many countries this variable is indeed capturing a significant determinant of their military spending. Comparing the models with homogenous and heterogenous potential enemies variables, the adjusted $\mathrm{R}^{2}$ is much higher in the latter, as is the log-likelihood, while the restriction that the individual potential enemies coefficients are equal is very strongly rejected by both a $\mathrm{F}$ and likelihood ratio tests.

To break down the effect of the 'Potential Enemies' military spending variable into those caused by changes in military spending and those by changes in hostility levels, countryspecific dummy variables were constructed for each country where some other country either entered or left the group of 'Potential Enemies' for the country in question, that is where a relationship of hostility was deemed to have begun or ended. For some countries, more than one dummy was constructed in respect of different rivals whose status changed over the period. The dummies were in all cases set to one for the period when the other country was in the Potential Enemies (including Enemies) category. ${ }^{6}$

When the model was estimated together with the country-specific break dummies, the signs of the variables remained the same, although population became insignificant. War and GPE were still positive and significant, democracy still negative and significant, and Security Web military spending still negative and marginally significant. Of 52 break dummies not dropped due to perfect multicollinearity, 22 were positive and significant, 10 were negative and

\footnotetext{
${ }^{6}$ Thus for example, there was a variable set to 1 for Israel only for the period 1981-1994, the year when a peace treaty was signed with Jordan, and zero for all other countries and for Israel post-1994. Likewise a dummy was created for Jordan for the years 1981-94. This is a fairly blunt instrument, but does go some way towards separating the different possible causes of changes in the Potential Enemies variable. A few such rivalries were excluded, where it was judged that they were unlikely to affect milex, in particular when there was a large disparity of power between the countries in question.
} 
significant, 11 were positive and insignificant, and 9 were negative and insignificant and coefficient estimates varied from 1.3 to $-1.9^{7}$. Interestingly, the Potential Enemies' military spending variable remained positive, but insignificant and of considerably smaller magnitude ${ }^{8}$. While not conclusive, this does suggest that changes in hostility levels may be at least as important in changes in the military spending of an existing rival in influencing military spending demand.

The results in Table 2 show, for each country which had at least one Potential Enemy at some point, the signs and significance of the country-specific Potential Enemies dummy and the country-specific break dummies respectively, with the rival countries whose status changed over the period shown in brackets in the second column. In only 8 of the 24 positive and significant coefficients for the country-specific Potential Enemies variable (shown in bold) was this not explained (at least partially) by a positive and significant coefficient on a change in hostility.

In the case of Bangladesh, Burma, Colombia, Venezuela and North Korea, there was no change in hostility. (Interestingly, the first four are two pairs of vaguely hostile nations.) The other three are Iraq, which as noted is anomalous, Jordan (where the break coefficient is insignificant) and South Africa (where there are three - possibly multi-collinear - break dummies.) In two cases - Israel and Thailand - there was a rather curious result where the Potential Enemies military spending variable was negative and significant, but the break dummy positive and significant. The first case is perhaps fairly explicable - Israel's overwhelming conventional (and nuclear) military supremacy may mean they do not have to worry about the military spending levels of opposing countries, but the removal of a specific enmity from the picture, indeed an immediate neighbour with a border also with the occupied West Bank, might well affect overall threat perceptions. This is perhaps an illustration of the heterogeneity of influences on threat perceptions and thus military spending for different countries, and different dyads. There are other results that suggest further investigation - for example the positive and significant coefficient on PE military spending for India may be a combination of an arms race with Pakistan and the lessening of hostility with China (where

\footnotetext{
${ }^{7}$ The latter case is highly idiosyncratic, namely Iraq, which gained a whole lot of enemies from 1990, but whose military spending dropped dramatically due to sanctions.

${ }^{8}$ Note that there was no break dummy for those relationships where hostility persisted throughout the period, e.g. India-Pakistan, Greece-Turkey, Israel-Syria, and thus the Potential Enemies military spending variable is the only thing that captures these rivalries.
} 
there is a positive and significant break dummy) -but overall the results do suggest that changes in hostility may provide a substantial part of the explanation of changes in a countries military spending. 
Table 2 - signs and significance levels of country-specific variables for regressions in sections 4 .

\begin{tabular}{|c|c|c|}
\hline Country & Potential Enemies Milex & Break dummy/ies \\
\hline Algeria & $+\operatorname{sig}$ & +sig (Morocco) \\
\hline Argentina & $+\operatorname{sig}$ & + sig (Chile) \\
\hline Bahrain & $+\operatorname{sig}$ & + sig (Iran) \\
\hline Bangladesh & + sig & \\
\hline Bolivia & -ins & \\
\hline Burkina Faso & $-\operatorname{sig}$ & -sig (Mali) \\
\hline Burma & + sig & \\
\hline Cameroon & +ins & \\
\hline Chad & -ins & -ins (Libya) \\
\hline Chile & -ins & -ins (Argentina) \\
\hline China & $+\operatorname{sig}$ & +sig, +sig (India, Russia) \\
\hline Colombia & + sig & \\
\hline Cuba & $+\operatorname{sig}$ & + sig (South Africa) \\
\hline Cyprus & $+\operatorname{sig}$ & \\
\hline Ecuador & -sig & \\
\hline Egypt & $+\operatorname{sig}$ & + sig (Libya) \\
\hline El Salvador & $+\operatorname{sig}$ & +sig (Honduras) \\
\hline Ethiopia & $+\operatorname{sig}$ & + sig (Somalia) \\
\hline Honduras & $+\operatorname{sig}$ & +sig (El Salvador) \\
\hline India & $+\operatorname{sig}$ & $+\operatorname{sig}($ China) \\
\hline Iran & & +sig, -sig (Saudi, Turkey) \\
\hline Iraq & + sig & -sig (Post 1990) \\
\hline Israel & -sig & $+\operatorname{sig}($ Jordan) \\
\hline Jordan & + sig & +ins. (Israel) \\
\hline North Korea & + sig & \\
\hline South Korea & -ins & \\
\hline Kuwait & $+\operatorname{sig}$ & + sig \\
\hline Libya & + +ins & +sig, +ins. (Chad, Egypt) \\
\hline Malawi & $+\operatorname{sig}$ & $+\operatorname{sig}($ Zambia) \\
\hline Morocco & + ins & +ins (Algeria) \\
\hline Mozambique & + ins & -ins (South Africa) \\
\hline Nigeria & -sig & -ins, -ins (Chad, Cameroon) \\
\hline Oman & -ins & -sig, -sig (Iraq, Yemen) \\
\hline Pakistan & + ins & \\
\hline Peru & - sig & \\
\hline Saudi & + +ins & +ins, -ins (Iran, Iraq) \\
\hline Senegal & -sig & -sig \\
\hline South Africa & + sig & +ins,-ins,+ins $(1988,1990,1994)$ \\
\hline Sudan & +ins & $\begin{array}{l}\text {-ins,+ins (Ethiopia, } \\
\text { Egypt/Uganda/Eritrea) }\end{array}$ \\
\hline Syria & -sig & -sig (Iraq) \\
\hline Taiwan & +ins & \\
\hline Thailand & -sig & +sig (Vietnam/Cambodia) \\
\hline Turkey & +ins & $+\operatorname{sig}($ Iraq) \\
\hline Uganda & $+\operatorname{sig}$ & +sig (Sudan) \\
\hline Venezuela & + sig & \\
\hline Vietnam & + +ins & \\
\hline Yemen & + +ins & -ins, -sig (S. Yemen, Saudi) \\
\hline Zambia & $+\operatorname{sig}$ & $\begin{array}{l}\text {-ins, +sig (Zaire/Zimbabwe, } \\
\text { South Africa) }\end{array}$ \\
\hline Zimbabwe & + sig & $\begin{array}{l}\text { +sig, +sig (Zambia, South } \\
\text { Africa) }\end{array}$ \\
\hline
\end{tabular}




\section{Conclusions}

This paper has considered an important question that arises from the developing literature that considers the demand for military spending in a general model with arms race and spillover effects in cross-section and panel data models. It questioned whether it is meaningful to talk of an 'arms race' in panel data or cross-section data, and suggested that it may be more appropriate to talk about the relevant variables - aggregate military spending of the 'Security Web’ (i.e. all neighbours and other security-influencing powers) and the aggregate military spending of 'Potential Enemies'- as acting as proxies for threat perceptions. Thus, while general Security Web variables may be indicative of arms races, or at least of emulation effects, they could also indicate common regional threat perceptions that cause neighbouring countries' military spending levels to tend to rise or fall together. When the aggregate military spending variable is restricted to a country’s rivals, it becomes a composite variable that follows changes in both military spending levels and in hostility ${ }^{9}$.

Taking the demand model in Dunne \& Perlo-Freeman (2003b) the study added countryspecific Potential Enemies military spending variables, which confirmed that the overall Potential Enemies result masks a great deal of heterogeneity, but also finding that this variable has a positive and significant coefficient for many countries. When break dummies are constructed to track changes in hostility between specific dyads,the results suggested that changes in hostility seem to account for a substantial proportion of the influence of the Potential Enemies' military spending variable on the demand equation.

Overall, the results suggest that in analysing the demand for military spending, even between two mutually hostile powers, it is important to look at the whole nature of the relationship between them, and not just look for Richardsonian action-reaction patterns.

\section{$\underline{\text { References }}$}

Collier, P. and Hoeffler, A. (2004), Military Expenditure: Threats, Aid and Arms Races.

\footnotetext{
${ }^{9}$ Indeed, it could be argued that in dyadic arms races also, a better understanding of the demand for military spending may be obtained by looking at hostility levels as well as action-reaction patterns of military expenditure.
} 
Dunne, J.P., Perlo-Freeman, S. and Smith, R. (2007) "Determining Military Expenditures: Arms Races and Spill-Over Effects in Cross-Section and Panel Data”, Mimeo, UWE Bristol.

Dunne, J.P. \& Smith, R. (2007), “The Econometrics of Military Arms Races”, Chapter 10 in (Hartley \& Sandler ed.) Handbook of Defence Economics, North-Holland.

Dunne J. Paul, Eftychia Nikolaidou and Ron Smith (2003) Arms Race Models and Econometric Applications, in Arms Trade, Security and Conflict edited by Paul Levine and Ron Smith, Routledge p178-187.

Dunne, JP and Perlo-Freeman, S (2003a) "The Demand for Military Spending in Developing Countries”. International Review of Applied Economics, Vol. 17, no. 1, 2003, pp. 23-48.

Dunne, JP and Perlo-Freeman, S (2003b) “The Demand for Military Spending in Developing Countries: A Dynamic Panel Analysis”. Defence and Peace Economics, Vol 14, No. 6, 2003, pp. 461-474.

Fuertes A-M and R.P. Smith (2005) Panel Time Series, Cemmap course notes.

Oren, I. (1994): “The Indo-Pakistani Arms Competition - a Deductive and Statistical Analysis”, Journal of Conflict Resolution, Vol. 38 no. 2 pp 185-214

Murdoch, J.C. and Sandler, T (2002) Economic growth, civil wars, and spatial spillovers, Journal of Conflict Resolution, 46 91-110.

Murdoch, J.C. and Sandler, T (2004) Civil Wars and Economic Growth: Spatial Dispersion, American Journal of Political Science 48(1), 138-151.

Polachek, S., Seiglie, C. and Xiang, J. (2005) “Globalization and International Conflict: Can FDI Increase Peace?”, Rutgers University Newark Working Paper \#2005-004.

Rosh, R. M. (1988): 'Third World Militarisation: Security Webs and the States they Ensnare', Journal of Conflict Resolution vol.32 no.4, pp 671-698.

Richardson, L. F. (1960): Arms and Insecurity: A Mathematical Study of Causes and Origins of War. Pittsburgh: Boxwood Press.

Smith, R. P . Sola, M and Spagnolo, F (2000) “The Prisoner’s Dilemma and RegimeSwitching in the Greek-Turkish Arms Race”, Journal of Peace Research, 37, 6 pp 737-750.

Smith, R.P. and A. Tasiran (2005) The demand for arms imports, Journal of Peace Research, 42(2), 167-182. 